\title{
スマートセンサを用いた柔軟はりのフィードフォワード型波動制御*
}

\author{
岩 本宏 之*1, 田中信 雄*2
}

\section{Active Wave Feedforward Control of a Flexible Beam Using Smart Sensors}

\author{
Hiroyuki IWAMOTO and Nobuo TANAKA*3 \\ ${ }^{* 3}$ Department of Mechanical Engineering, Tokyo Metropolitan Institute of Technology, \\ 6-6 Asahigaoka, Hino-shi, Tokyo, 191-0065 Japan
}

\begin{abstract}
This paper deals with active wave control of a flexible beam using a wave filter constructed with smart sensors. It is the purpose of this paper to present a novel wave filtering method using PVDF film sensor and its application for adaptive feedforward control system. Firstly, the design procedure of the wave filter using shaped PVDF sensors is presented. When introducing PVDF sensor, shaping function is defined as a complex function. In this case, multiplying an imaginary unit is equivalent to making the phase difference of 90 degree. Next, from a viewpoint of numerical analysis, the accuracy of the wave filter and the performance of the control system is clarified. Finally, an experiment of the active wave feedforward control system is carried out, demonstrating the validity of the proposed method.
\end{abstract}

Key Words : Vibration, Flexural Wave, Flexible Beam, Active Wave Control, Wave Filter, Smart Sensor, Adaptive Feedforward Control

\section{1. 粕言}

近年, 知的適応構造 (スマートストラクチャ) (1)にお ける機能材料としてPZT, PVDFフィルムに代表される 圧電材料が注目されている.知的適応構造とは構造, 機 構，制御が融合し一体化することにより，構造自体が 㻴境の変化に応じてその特性を自律的に適応させ，常 に自己の最適化を図る構造のことを言う。この概念は 種々の分野に波及し，振動・䭷音制御分野においても 例外ではなく，圧電材料を振動制御センサに利用する 研究がさかんに行われている.

圧電材料をセンサに利用する利点は，当該センサを 任意の形状関数に基づいたシェーピングすることによ り、センサ自体に空間積分機能を付与する,すなわち, 信号処理における積和演算機能を付加できる点にある. したがって、最適設計された分布定数系センサはス マートセンサとしての機能を具備する. 例えば, Leeら はPVDFフィルムを柔軟はりのモードセンサ(2)に応用し，

* 原稿受付 2004 年 8 月 17 日.

*1 正員, 東京都立科学技術大学大学院工学研究科 (邑 191-0065 日野市旭が丘 6-6)

*2 正員, フェロー, 東京都立科学技術大学工学部.

E-mail : ntanaka@cc.tmit.ac.jp
モード形状関数の 2 階微分の形状にPVDF フィルムを シェーピングすることで, 対象モードの振幅のセンシ ングが可能となることを明らかにしている．また，田 中らはPVDFセンサを薄肉平板の振動モードセンサ (3), あるいは音響パワーモードセンサ(4) として応用してい る.しかし，これらの研究を総括すると，末だモード 制御法 ${ }^{(2) \sim(7)}$ に基づいたものが多く, 波動制御法 ${ }^{(8)}$ ( (15) の観点から振動制御問題を論じた報告はない.

波動制御法は，分布定数系構造物が有する無限個の 振動モードの構成要素となる進行波，あるいは反射波 を除去することにより，全振動モードを不活性化する 制御法である．著者らはこれまでに，波動フィルタを 基調とした適応型フィードフォワード波動制御系を構 築し，その有用性を実験により実証した ${ }^{(13)(14)}$. しかし ながら，当該フィルタの構成にあたってはポイントセ ンサを用いていたため，対象システムに対する質量の 付加は避けられず，産業用マニピュレータのような軽 量高速化が求められるシステムへの応用が困難である ことが予想される.

そこで，本論文は前述の知的適応構造を志向し，圧 電フィルムをシェーピングすることにより，はりを伝 播する波動をセンシングし，これをベースとする適応 
型フィードフォワード波動制御系を構筑することを目 的とする. まず，オイラー・ベルヌーイはりを対象に 進行波解を求めることから始め, 次いで, スマートセ ンサによる波動フィルタの設計法を提示する.さらに， 数値解析により, 両端固定はりにおけるフィルタリン グ精度と当該フィルタを用いた場合の制御効果を検証 する. 最後に, 波動フィルタを用いた適応型フィード フォワード制御系の実験を行い，その有用性を実証す る.

\section{2.スマートセンサによる波動フィルタ}

これまでの振動制御法は，モード解析に基礎を置く モード制御が主流であったことから，はりの運動方程 式の解はモードの重畳によって表されるのがほとんど であった：しかし，本論文では波動の観点から振動制 御問題を論ずるため, はりの波動解を導くことから始 める. まず，任意の境界条件を有するオイラー・ベル ヌーイはりに, 調和分布力 $f(x, t)$ が作用する場合, その 運動方程式は次のように表される.

$$
E I \frac{\partial^{4} \xi(x, t)}{\partial x^{4}}+\rho A \frac{\partial^{2} \xi(x, t)}{\partial t^{2}}=f(x, t)
$$

ここで, 式(1)を解くために，その斉次方程式を考え， その解を $\xi(x, t)=\xi(x) e^{j \omega x}$ と置き, 上式を変数分離すると次 のようになる.

$$
\frac{d^{4} \xi(x)}{d x^{4}}-k^{4} \xi(x)=0
$$

ただし

$$
k^{4}=\rho A \omega^{2} / E I
$$

ここで, $E, I, \xi, x, t, \rho, A, \omega, j, k$ は, 各々繸弾性係数, 断面二次モーメント, 曲げ振動の変位, はりの左端か らの距離, 時間, 密度, 断面積, 角振動数, 虚数単位, 波数を表す.すると, 式(2)の一般解は次のように求ま る.

$$
-\xi(x)=c_{1} e^{-j k x}+c_{2} e^{-k x}+c_{3} e^{j k x}+c_{4} e^{k x}
$$

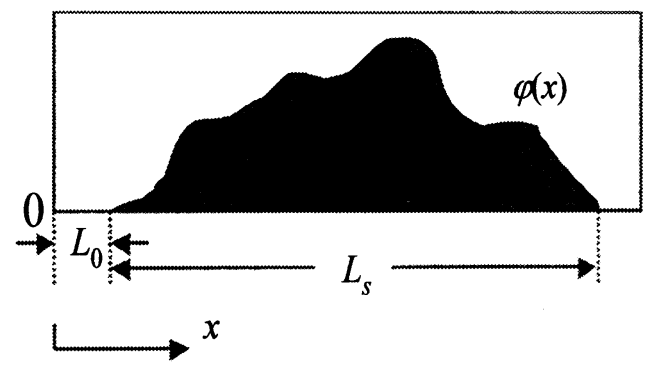

Fig.1 One-dimensional distributed parameter PVDF sensor shaped in the width direction and placed along $x$-axis
ただし， $c_{1}, c_{2}, c_{3}, c_{4}$ はそれぞれ進行波振幅，はりの左 端より減衰するニア・フィールドの振幅, 後退波振幅, はりの右端より減衰するニア・フィールドの振幅を表 す.ここで, 境界から十分に離れた領域に注目すると， 当該領域においてはニア・フィールドの影響を無視で きるので, 式(4)は次のように近似される.

$$
-\xi(x)=c_{1} e^{-j k x}+c_{3} e^{j k x}
$$

次に, 図 1 に示すように形状関数 $\varphi(x)$ によってシェー ピングされた長さ $L_{s}$ の分布定数系PVDFセンサ (スマー トセンサ）が，柔軟はりに貼付されている場合を考え る. すると，スマートセンサの電荷出力振幅は次式で 与えられる。

$$
\tilde{q}=\Gamma_{0} e_{31} \int_{L_{0}}^{L_{0}+L_{s}} \varphi(x) \frac{d^{2} \xi(x)}{d x^{2}} d x
$$

ただし, $\Gamma_{0}$ はセンサ定数, $e_{31}$ は圧電応力定数である.

ここで，スマートセンサのシェーピング関数を次の ように定義する.

$$
\varphi(x)=e^{a x}
$$

ただし，aは任意の定数である. 次に, 式(5)と式(7)を 式(6)に代入すると, 波動解を基調とした, ファー・ フィールドにおけるスマートセンサの電荷出力振幅が 次式のように表される.

$$
\begin{aligned}
\tilde{q}=\Gamma_{0} e_{31} k^{2}\left\{\frac{c_{1} e^{(a-j k) L_{0}}}{a-j k}\left(e^{(a-j k) L_{s}}-1\right)\right. \\
\left.+\frac{c_{3} e^{(a+j k) L_{0}}}{a+j k}\left(e^{(a+j k) L_{s}}-1\right)\right\}
\end{aligned}
$$

上式より，例えば，後退波振幅をセンシングしようと する場合, 進行波振幅 $c_{1}$ の項を零とする必要がある.す なわち

$$
\frac{c_{1} e^{(a-j k) L_{0}}}{a-j k}\left(e^{(a-j k) L_{s}}-1\right)=0
$$

ここで, 複素指数関数の周期性に着目すると

$$
e^{2 m j \pi}-1=0 \text { (ただし, } m \text { は任意の整数) }
$$

であるから，後退波振幅のフィルタリング条件は次式 で表される.

$$
(a-j k) L_{s}=2 m j \pi
$$

ただし，上式において $m=0$ の場合，すなわち， $a=j k$ の 場合, 式(9)は次式のようになり,明らかに非零である.

$$
\lim _{a \rightarrow j k} \frac{c_{1} e^{(a-j k) L_{0}}}{a-j k}\left(e^{(a-j k) L_{s}}-1\right)=c_{1} L_{s}
$$

したがって， $m$ は非零でなければならない。この条件 下において式(11)を満たす $a$ と $L_{s}$ は次式で与えれらる. 


$$
\begin{aligned}
& a=-j k \\
& L_{s}=\frac{n \lambda}{2}(\text { ただし, } n \text { は任意の整数 })
\end{aligned}
$$

ただし，入は波長を表す。また， $n$ はセンサの長さに関 寸る係数であるので, 本研究ではこれをセンサ長係数 と呼ぶ.この係数は, 数学的には任意の整数であるが, センサの長さを決定付けるものなので，負の值，需お よびセンサの長さがはりの長さを超えるような值はと りえない.このとき, PVDFフィルムの電荷出力振幅は, 式(13)および式(14)を式(8)に代入することにより（極 限操作になることに注意)，次のように求まる.

$$
\tilde{q}=\frac{\Gamma_{0} e_{31} k^{2} c_{3} n \lambda}{2}
$$

上式より明らかなように，進行波振幅の項が取り除か れ，後退波振幅のみがフィルタリングされているのが わかる。ここで，ひとつ問題点が生じる。それは，式 (7) と式(13)より明らかなように, シェーピング関数が 複素指数関数となる点である。この問題の解決方法を 以下に示す。まず，複素指数関数をオイラーの公式に より次のように展開する.

$$
e^{-j k x}=\cos k x-j \sin k x
$$

上式は複素関数によるシェーピング法を示す。すなわ ち, $\cos$ 関数によってシェーピングされたセンサの出力 に, sin関数でシェーピングされたセンサの出力に虚数 単位を掛けたものを加えればよい。この場合, 虚数単 位は陽であるので，この操作は信号の位相を 90 度シフ トする事と等価である、その証明は次のとおりである. PVDFセンサの電荷出力は出力振幅 $\tilde{q}$ を用いて次のよ うに表される。

$$
q(t)=\operatorname{Re}\left[\tilde{q} e^{j \omega t}\right]
$$

ここで，時間に関する項 $e^{j \omega t}$ を実部と虚部に展開し，出 力振幅の式に式(16) を代入することにより, 複素指数 関数によってシェーピングされたセンサ出力が次のよ うに表される。

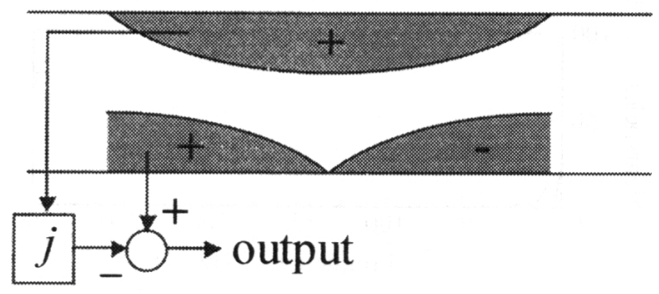

Fig.2 Schematic diagram of a wave filter using shaped PVDF films

$$
\begin{aligned}
q(t)= & \Gamma_{0} e_{31} \int_{L_{0}}^{L_{0}+L_{s}} \cos k x \operatorname{Re}\left[\frac{d^{2} \xi(x)}{d x^{2}}\right] d x \cdot \cos \omega t \\
& +\Gamma_{0} e_{31} \int_{L_{0}}^{L_{0}+L_{s}} \cos k x \operatorname{Im}\left[\frac{d^{2} \xi(x)}{d x^{2}}\right] d x \cdot(-\sin \omega t) \\
& +\Gamma_{0} e_{31} \int_{L_{0}}^{L_{0}+L_{s}} \sin k x \operatorname{Re}\left[\frac{d^{2} \xi(x)}{d x^{2}}\right] d x \cdot \sin \omega t \\
& +\Gamma_{0} e_{31} \int_{L_{0}}^{L_{0}+L_{s}} \sin k x \operatorname{Im}\left[\frac{d^{2} \xi(x)}{d x^{2}}\right] d x \cdot \cos \omega t
\end{aligned}
$$

上式の右辺第一項および第二項は $\cos$ 関数によって シェーピングされたセンサに関して, 複素変位振幅の の実部と虚部に対応する出力を示している.同様に, 第 三項および第四項はsin関数によってシェーピングされ たセンサに関して, 複素変位振幅の実部と虚部に対応 する出力を示す.ここで各項の時間成分に注目すると， 第三項と第四項の位相が第一項と第二項に対して，そ れぞれ-90度シフトしているのがわかる。これは, ある 信号に虚数を掛けるということは，その信号に 90 度の 位相差を与えることと等価であることを示している。 この場合の波動フィルタの概要図を図 2 に示す.

\section{3. 波動フィルタの数値解析}

3・1 波動フィルタの精度の検証 前章にお いて，スマートセンサによる波動フィルタリング法を 明らかにした。それによれば，シェーピング関数は波 数の関数であり，それに対応するセンサの長さは波長 の関数である.したがって，当該フィル夕はひとつの 周波数（基本周波数）を対象に設計される。また， ファー・フィールドにおける変位式を基調とするので, ニア・フィールドの寄与が大きい変位が生じた場合, フィルタリング精度に大きな影響を与える可能性があ る. そこで, 本章では基本周波数以外の外乱が注入さ れた場合に，当該フィルタがどこまで精度を保持でき るかを検証する.なお, はりの諸元は表 1 に示されてい るものを使用し，境界条件は固定・固定とする．また， モード周波数におけるオーバーフローを避けるため,

Table 1 Design parameters of a flexible beam

\begin{tabular}{|c|c|c|}
\hline Total length & Thickness & Width \\
\hline $1.105 \mathrm{~m}$ & $1.5 \mathrm{~mm}$ & $4.5 \mathrm{~cm}$ \\
\hline Young's modulus & Density & Material \\
\hline $7.4 \times 10^{10} \mathrm{~N} / \mathrm{m}^{2}$ & $2770 \mathrm{~kg} / \mathrm{m}^{3}$ & Duralumin \\
\hline
\end{tabular}


損失係数 0.001 を与える.

スマートセンサをはりの中央に設置し，外乱がはり の右端から $5 \mathrm{~cm}$ の位置に作用する場合を考える．波動 フィルタの基本周波数を4次モード周波数 $(58.31 \mathrm{~Hz})$ と し，センサ長係数を $n=4,2,1$ とした場合の波動フィル タの出力に含まれる各波動成分の比が図3～5に示され ている. $n=4$ の場合（図3），基本周波数において後退波 成分は最大值 (96. 1\%) をとり, 進行波成分およびニア.
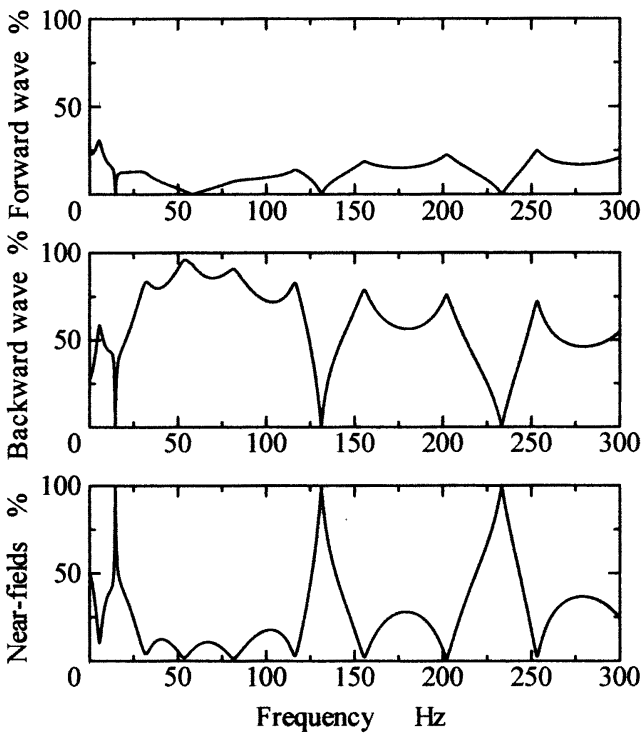

Fig.3 Ratios of the wave component to total output of the wave filter designed for the 4th modal frequency in the case of $n=4$
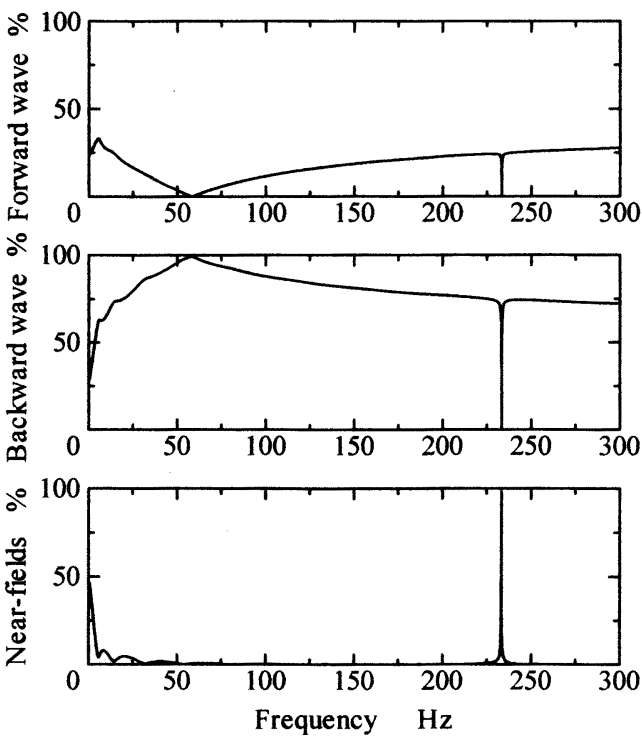

Fig.4 Ratios of the wave component to total output of the wave filter designed for the 4th modal frequency in the case of $n=2$
フィールド成分においてはノッチが生じている.また， 後退波成分は $300 \mathrm{~Hz}$ までの帯域において3つのノッチを 持っている. これは基本周波数における波長が実際の 波長の 0.5 分の $1,1.5$ 分の 1,2 分の 1 となる場合であ る. 次に, ニア・フィールド成分について注目すると, 後退波成分がノッチとなる周波数において $100 \%$ とっ ている.すなわち，これらの周波数においてはフィル タ出力はニア・フィールド成分のみを持つことになる.

次に, $n=2$ の場合（図 4)について考える.この場合， 基本周波数における波長が実際の波長の整数分の 1 と なる場合（基本周波数は除く）にノッチを持ち, $300 \mathrm{~Hz}$ までの帯域において，ノッチの数は $n=4$ の場合よりも 少ない.これは，センサの長さが短くなったことによ るものである．また，ノッチ近辺での勾配が $n=4$ の場 合に比べて急になっており，ノッチ周波数近傍での精 度が向上しているのがわかる。これらの結果は，セン サ長係数が波動フィルタの精度の支配因子であること を示している. 寸なわち，センサ長係数が小さくなる ほどフィルタリング精度が向上する。

$n=1$ の場合(図 5), $300 \mathrm{~Hz}$ までの帯域においては, 後 退波成分はノッチを持たないのがわかる。これはここ れまでのケースに比べて波動フィルタの精度が最大に なっていることを示している. しかし，当該領域には 示されていないが，基本周波数における波長が実際の 波長の奇数分の 1 となる場合 (基本周波数を除く) に後 退波成分はノッチを持つ.

以上より，センサ長係数が小さいほどフィルタリン
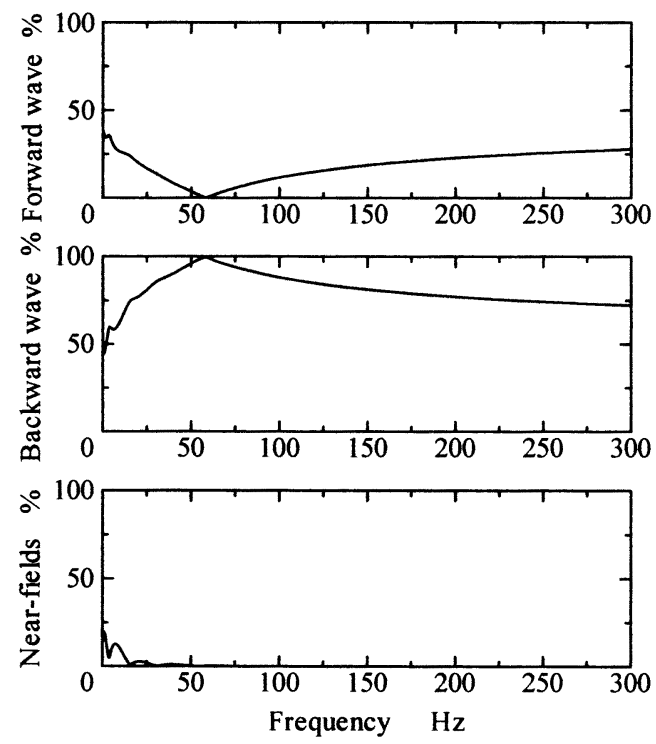

Fig.5 Ratios of the wave component to total output of the wave filter designed for the 4 th modal frequency in the case of $n=1$ 
グ精度は向上するものの, 当該係数が1の場合において も反射波成分はノッチを持つことが明らかになった. 実際に制御系を設計する場合，モード周波数とノッチ 周波数が一致することは避けなければならない，そこ で，反射波成分および進行波成分がノッチを持つ条件 を以下に示す.

まず，シェーピング関数とセンサの長さを次のよう に設定する.

$$
\begin{aligned}
& \varphi(x)=e^{-j k_{T} x} \\
& L_{s}=\frac{n \lambda_{T}}{2}
\end{aligned}
$$

ただし， $k_{T}$ と $\lambda_{T}$ はそれぞれ基本周波数に対応する波数 と波長である.ここで, 式(19) と式(20)を式(8)に代入 し，反射波成分と式(10)を比較することで，当該成分 がノッチを持つ条件が次のように導かれる.

$$
\frac{\lambda_{T}}{\lambda}=\frac{2 m+n}{n}
$$

さらに, 波長が負の值をとることはないので, $m$ は次 式を満たす。

$$
m>-\frac{n}{2}
$$

ただし，第2章において示したように，mは非零である. また，同様の手順により，進行波成分がノッチを持つ 条件が次のように得られる.

$$
\frac{\lambda_{T}}{\lambda}=-\frac{2 m+n}{n}
$$

ただし,この場合の $m$ は次式を満たす.

$$
m<-\frac{n}{2}
$$

ここで, 式(22)と式(24)が互いに相反する条件を示し ているが, $m$ は式(10)に示されるように複素指数関数 の周期性を意味するものであり，理論展開の中で必ず しも同じ值をとる必要はない点に留意されたい.

次に，具体的な例として $n=4$ の場合について考える. この場合, 式(22)を満たす $m$ は-1，1，2，․となる.こ れらの値を式(21)に代入すると，反射波成分がノッチ を持つ条件は，基本周波数における波長が実際の波長 の 0.5 分の $1,1.5$ 分の 1,2 分の 1 となる場合となり, 数 值解析の結果と一致する，次に，進行波成分に注目す ると，同様の手順により，当該成分がノッチを持つ条 件は，基本周波数における波長が実際の波長の 0.5 分 の 1,1 分の 1 (基本周波数と一致)，1.5 分の 1 となる場 合である。これを反射波の条件と比較すると，基本周 波数以外における双方のノッチ周波数が一致すること がわかる.したがって、これらの周波数における波動 フィルタの出力はニア・フィールドのみに依存する.
以上より，反射波成分がノッチを持つ条件が明らか になった．波動フィルタの設計の際には，この条件を 基に，モード周波数とノッチ周波数が一致することを 避ける必要がある。

3・2 制御効果の検証本節では分布定数系 センサによる波動フィルタを用いた場合の制御効果を， 変位波動包絡線の観点から検証する．また，比較対象 としてアクティブ・シンク法(10)(11)の制御効果も併せて 提示する．当該手法は，柔軟はりの波動制御法におけ る最適制御状態を示すことから，提案する手法の良い 評価指標となる。なお，制御法は反射波吸収制御法を 対象とし, 外乱点ははりの右端から $5 \mathrm{~cm}$ の位置に, 制御 点は左端から $5 \mathrm{~cm}$ の位置に, スマートセンサははりの中 央に設置するものとする.

非制御時およびアクティブ・シンク法適用時の波動 包絡線 (2 次および 4 次モード)が図 6 に示されている.
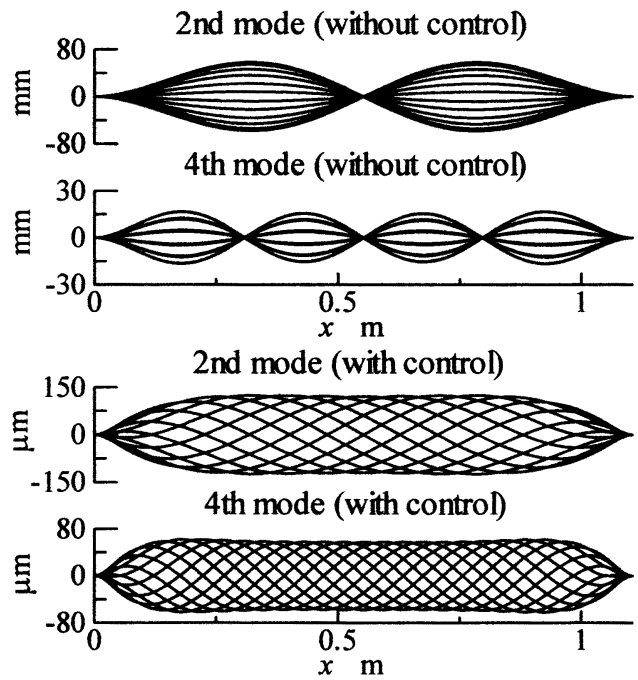

Fig.6 Envelope of displacement distribution around the 2 nd and the 4 th modal frequency with and without active sink

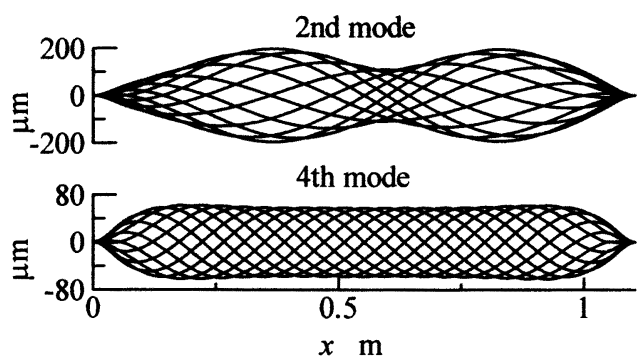

Fig.7 Envelope of displacement distribution around the 2nd and the 4th modal frequency with control using proposed wave filter in the case of $n=1$ 
非制御時の場合，定在波と振動モードの形状が一致す ることにより，振動モードが励起された状態にあるの がわかる.当然のことながら，振動の節は移動しない， これに対し，アクティブ・シンクを設置した場合，定 在する節は消滅し，振動変位は進行波と二ア・フィー ルドのみに依存する．また，振動モードが不活性化さ れているため, 変位はそれぞれ0.21\%，0.37\%までに抑 制されている，次に，基本周波数が 4 次のモード周波 数, センサ長係数が1である分布定数系センサを用いた 場合の波動包絡線について考える。この場合の波動包 絡線が図 7 に示されている.4次モードに注目すると， 基本周波数と加振周波数が一致しているため，アク ティブ・シンクと全く同じ制御効果が得られているの がわかる。これに対し，2次モードの場合，はりの中央 に定在していた節は移動するものの，波動フィルタの フィルタリング誤差により反射波成分が残留するため,

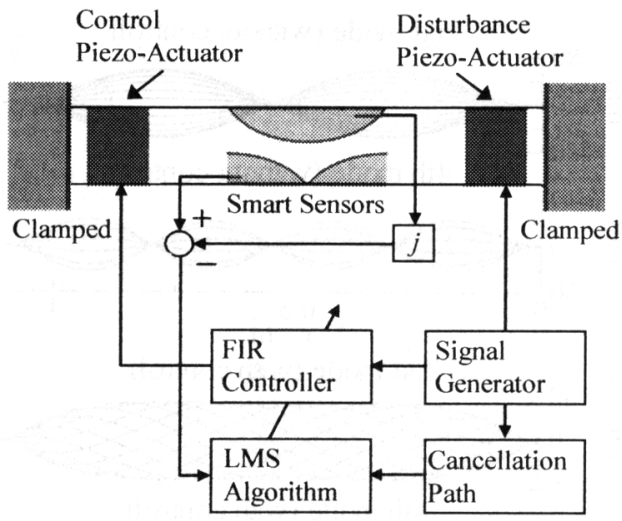

Fig.8 Schematic diagram of adaptive feedforward control system using wave filter constructed with smart sensors

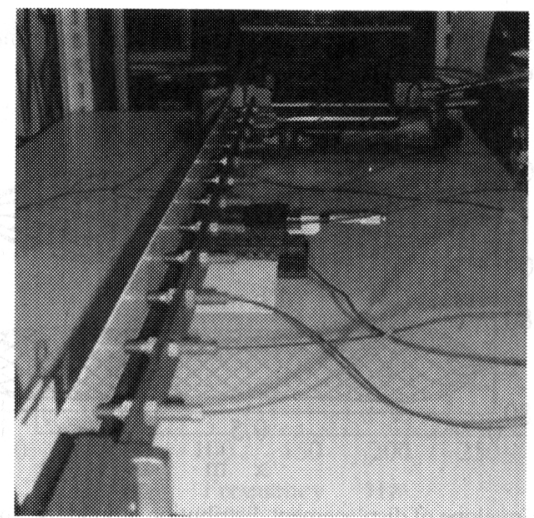

Fig.9 Picture of wave visualization system
包絡線の中央付近にくぼみができている。この時，最 大変位は非制御時の $0.34 \%$ となっており, 最適制御状態 に極めて近い制御効果が得られている。ここで，2 次 モード周波数において, 波動フィルタの出力に含まれ る反射波成分の比は約 $75 \%$ であることを鑑みると（図 5 参照)，当該制御系は非常にロバスト性能が高いこと が分かる。この結果は，評価関数に構造物中を伝播す る波動振幅を用いる限り，計測誤差に対して頑健な制 御系が構築されることを示している。

本数值解析では, 制御点の位置を外乱点に対して対 称の位置に設置したが，それ以外の点においた場合に おいても波動制御法は有効であることが田中らによっ て示されている(10)(11)。しかし，スマートセンサによる 波動フィルタを用いる場合，センサが貼付されている 領域には制御点を設置できないことに注意しなければ ならない

\section{4. 波動制御実験}

$4 \cdot 1$ 実験方法 図8 に制御系の概念図を示し ている、はりの境界条件は固定・固定とし，はりの両 端をバイスで支持することにより実現する。アクチュ エータにはパッチ型のピエゾ素子を用いる，外乱点は 右端から $5 \mathrm{~cm}$ の位置とし, 制御点は左端から $5 \mathrm{~cm}$ の位置 とする.制御方式にはfiltered- $x$ LMSアルゴリズムを基 調とする適応型フィードフォワード制御法を用いる。

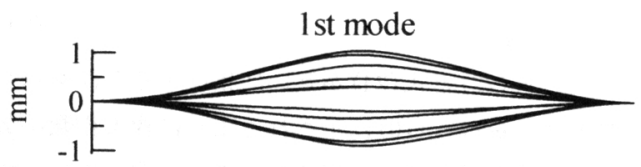

2nd mode

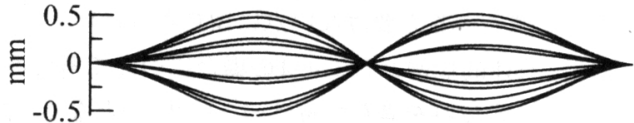

3rd mode

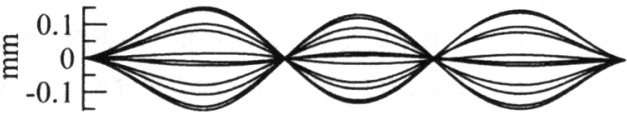

4th mode

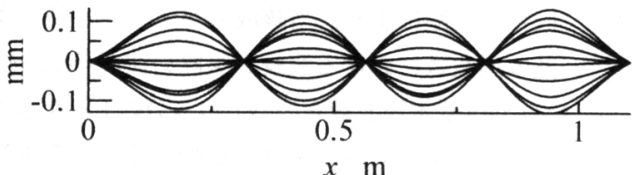

Fig.10 Experimental results of envelope of displacement distribution around the 1st though the 4th modal frequency without control 
コントローラとキャンセレーションパスのタップ数は 128 とする. また, 波動フィルタの基本周波数は 4 次の モード周波数に設定し, センサ長係数は1, 設置位置を はりの中央とする. 次に, 図9に示す波動可視化システ ムについて説明する. 当該システムは3章において示し た波動包絡線を実験的に得るためのシステムである. はりに沿って $8.5 \mathrm{~cm}$ 間隔に 12 個の非接触型ギャップセ ンサを設置し, データ・ロガーによって変位情報を同時 サンプリングする. 取り込まれた 12 点のデータは計算 機により信号処理が施され，さらにスプライン補間を することにより変位波動包絡線が得られる.

$4 \cdot 2$ 実験結果 1 次から 4 次のモード周波数 近傍における, 非制御時の変位波動包絡線が図10に示 されている. 当然のことながら, 定在波と振動モード の形状が同調することにより, 振動モードが励起され ている.この場合の各モード周波数における最大変位 は, 1 次から, $1.1 \mathrm{~mm}, 0.54 \mathrm{~mm}, 0.15 \mathrm{~mm}, 0.13 \mathrm{~mm}$ となっ ている. 次に, 図11に示される制御時の波動包絡線に ついて考える. 全てのモード周波数において, 非制御 時には定在していた節が移動しているのがわかる.こ れは, 制御力によって反射波が吸収されていることを 意味しており，波動制御法の典型的な特徽である．波 動フィルタの基本周波数である 4 次モードの場合に注 目すると, 包絡線に僅かながら起伏が生じている. こ れは, 微小量ながら反射波が残留していることを示し ており, PVDFフィルムのシェーピング誤差によるもの

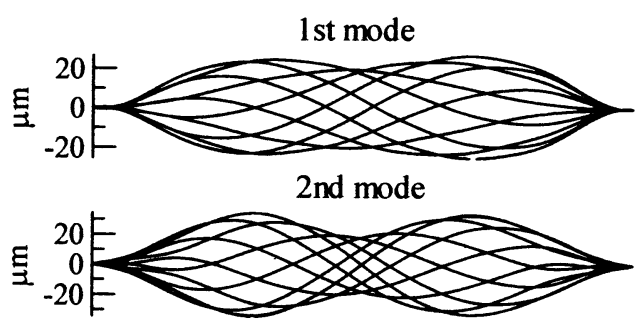

3rd mode

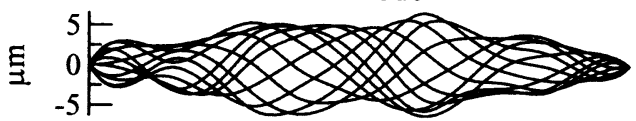

4th mode

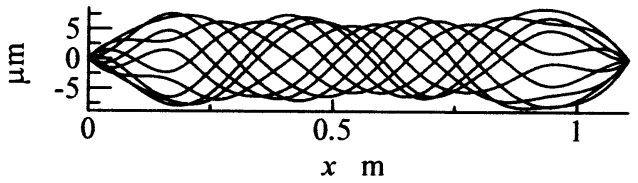

Fig. 11 Experimental results of envelope of displacement distribution around the 1st through the 4th modal frequency with control using wave filter designed for 4th modal frequency in the case of $n=1$
と考える. この場合の最大変位は $9 \mu \mathrm{m}$ となっており, 非 制御時の 6.9\%にまで抑制されている.これに対し, 基 本周波数以外のモードにおいては, フィルタリング誤 差により,包絡線の起伏が比較的大きく現れている.し かしながら,これらの場合の最大変位は, 1 次から, $27 \mu \mathrm{m}, 34 \mu \mathrm{m}, 7 \mu \mathrm{m}$ となっており, 非制御時の $2.5 \%, 6.3 \%$, 4.7\%にまで抑制されている.

この実験結果において特筆すべき点は, 基本周波数 以外の周波数においても制御系が高い性能を示すこと である.これはエラー信号が波動振偪であることに起 因する. 図5に示されるように, 基本周波数以外の周波 数における主なフィルタリング誤差とは，進行波成分 の混入である．波動フィルタの出力が誤差を含まない 場合, その出力の最小化は最適制御状態 (アクティブ. シンク）を実現することと等価である.これに対し，進 行波成分と反射波成分の比が $50 \%$ になる場合，その出 力を最小化するということは定在波型抑制(11)に帰結す る.この時の変位波動包絡線は定在波の形態をとるが， その形状は振動モードの形状とは一致しないため, モード励振が発生することはない.ささら，仮に進行 波成分が $100 \%$ なった場合にその出力を最小化すると， 外乱に向かって波動が流れ込む状態になる．これをア クティブ・ソース ${ }^{(11)}$ と呼ぶ. この時, 波動が流れる方 向は異なるが, その制御効果はアクティブ・シンクと 一致する.したがって，たとえ波動フィルタが誤差を 持ったとしても,その制御効果は上記の3つの状態の間 を遷移することになる. その結果, 当該制御系は非常 に高いロバスト性能を持つ。これは, 構造物中を伝播 する波動のフィルタリングを基調としているためであ り, 構造物中のある一点での状態量（変位, 傾き, 曲 げモーメント, せん断力）を評価関数とした場合では, ここまで高いロバスト性能を持つ保証はない.

\section{5. 結言}

本論文は, 柔軟はりを対象として, 知的適応構造物 (スマートストラクチャ) の観点から, スマートセンサ を用いた波動フィルタリング法を提案するとともに， 当該フィルタを基調とする適応型フィードフォワード 波動制御系を構築し, 当該手法の有用性を実証した. 本 論文で得られた成果を要約すると次のようになる.

1. 知的適応構造物, 特にスマートセンサの観点から, シェーピングされた分布定数系センサによる柔軟はり の波動フィルタリング法を明らかにした，その際， シェーピング関数は複素指数関数となるが，オイラー の公式により当該関数を実部と虚部に分割し, 陽と 
なった虚数単位を 90 度の位相差と捉えることで，ス マートセンサの具現化を行った.

2. 波動フィルタの設計においては, ファー・フィール ドにおける変位を基調としているため, 提案した波動 フィルタはニア・フィールドの影響を受ける.また， シェーピング関数が波数 (周波数) の関数となること から，一つの基本周波数を対象に設計される. そこで, 基本周波数以外でのフィルタリング精度を, フィルタ 出力中に含まれる波動要素の比によって評価した。 の結果, センサ長係数がフィルタリング精度の支配要 因であることが明らかになった.

3. 波動フィルタの信号を最小化した場合の制御効果 を，変位波動包絡線の観点より明らかにした。基本周 波数においては, 最適制御状態 (アクティブ・シンク法 適用時）と同様の制御効果を得ることができるが，そ の他の周波数においては，制御効果は劣化する．しか し，その程度は微小である.これは, 波動制御系の口 バスト性能が高いことを示している.

4. スマートセンサによる波動フィルタを filtered- $x$ LMSアルゴリズムを基調とする適応制御系のエラーセ ンサに適用することにより，適応型フィードフォワー ド波動制御系を構策した. 実験結果は数值解析例とよ く一致し，当該手法の有用性が実証された。

\section{文献}

(1) 田中信雄, “スマート・ストラクチャ（集中定数系から分布 定数系への変遷)”, 機論, 70-692, C(2004), 889.

(2) Lee, C.K. and Moon, F.C., "Modal Sensors/Actuators", ASME, J. Appl. Mech, 57, (1990), 434.

(3) Tanaka, N. et al., "One-Dimensional Modal Sensors and the Active Modal Control for Planar Structures", J. Acoust. Soc. Am., 121, (1998), 217.
(4) Tanaka, N. et al. "Distributed Parameter Modal Filtering Using Smart Sensors", ASME, J. Vib. Acoust, 118, (1990), 630.

(5) Balas, M.J., "Direct Velocity Feedback Control of large space structure", J.Guidance, 6-5, (1983), 351.

(6) Meirovitch, I., and Baruh, H., "The Implementation of Modal Filters for Control of Structure”, J.Guidance, 86, (1985), 706.

(7) Kosut, R.L., "Robust Control of Flexible Spacecraft", J.Guidance, 6-2, (1983), 104.

(8) Procopio, G.M., and Hubbard, J.E., "Active Damping of a Bernoulli-Euler Beam via End Point Impedance Control Using Distributed Parameter Techniques", 1987 ASME Design Technology Conference, (1987), 35.

(9) von Flotow, A.H., and Shafer, B.E., "Wave Absorbing Controllers for a Flexible Beam", J.Guidance, 9-6, (1986), 673.

(10) 田中信雄・菊島義弘，“柔軟はりの曲げ波制卸に関する 研究 (アクティブ・シンク法の提案)”，機論， 56-522, C(1990), 351 .

(11) 田中信雄・菊盘義弘, “柔軟はりの曲げ波制御に関する研 究 (アクティブ・シンク系の基本的性質とその検証)”，機 論, 56-530, C(1990), 2575.

(12) Gibbs, G.P. et al., "Active Control of Flexural and Extentional Power Flow in Beams Using Real Time Wave Vector Sensors", Proc. of 2nd conference on Recent Advances in Active Control and Vibration, (1993), 909.

(13) 岩本宏之・田中信雄, “柔軟はりにおける波動フィルタ リング法に関する研究（ポイントセンサ群による波動 フィルタの設計)", 機論, 68-675, C(2002), 3246.

(14) 岩本宏之・田中信雄, “ポイントセンサ群による波動フィ ルタを用いた柔軟はりのフィードフォワード型波動制御に 関する研究”，機論，69-685, C(2003), 2233.

(15) Iwamoto, H. and Tanaka, N., "Active Wave Control of a Flexible Beam Using Distributed Parameter Sensors", Proc. of the 6th International Conference on Motion and Vibration Control, (2002), 710.

(16) Snowdon, J.C., Vibration and Shock in Damped Mechanical Systems, (1986), 201, John Wiley \& Sons. 